\title{
CAUSES OF STUDENT ABSENTEEISM AT UNDERGRADUATE LEVEL: A STUDY
}

\section{Dr. Alaka Das}

\section{Asso. Prof. Dept Of Education. Kumar Bhaskar Varma Sanskrit Studies University, Nalbari}

\section{ABSTRACT}

The objective of the study is to study the reasons of student absenteeism from student's perspective. The study is qualitative in nature and descriptive survey method is applied. The sample of the study consists of 60 undergraduate students from three colleges of the area selected purposively who are in the habit of absenting oneself from regular classes. From above discussion it can be observes that the reasons of class absenteeism varied from personal, familial, peer group, teacher concerned, organizational to societal aspects.

KEYWORDS : Student Ābsenteeism, Undergraduate Level.

INTRODUCTION -

Absenteeism is a habitual pattern of absence from duty or obligation. The growing rate of absenteeism in the classes of undergraduate level include lack of accountability on the part of the students, teachers, defective system of education and lack of practical relevance of curriculum in daily life. Falling teaching standard and fear of poor performance in colleges drive the students to tuition centre. A little extra help outside the class, extra practice at coaching centres to stay ahead of the competition is expected by the parents when their children reach higher classes. In this study, an effort has been made to know the reason of absenteeism, from three institutions of higher education of Pub Kamrup area.

\section{STUDENT ABSENTEEISM -}

The term absenteeism has been defined as the conscious and deliberated action of being away from the physical space of the regular classroom conditioned for some factors that influence the search of alternatives to the use of time. Bowen (2005) has established that students who attend classes more regularly seem to be more successful in their studies than those who regularly absent. Some studies show evidence of the inverse relation between absenteeism and academic grade. Such studies also confirm the results of the literature including factors related to the nearness of examinations, the teaching skills, and the social commitments. Researchers have identified several possible reasons for this absence. Dhaliwal (2003) determined the reasons of the absenteeism of the students, from the most important to the least important, as the reasons rooting from illness, lecturer or the subject matter, familial reasons, individual studying, getting prepared for the examinations, rainy day, entertaining etc. However, literature considering the causes of abstaining from regular classes conducted in undergraduate level colleges of north east region has been observed to be not available.

\section{SIGNIFICANCE OF THE STUDY -}

Class absenteeism is considered a first order problem from the educational, social, economic and personal point of view. The reasons associated with lecture absenteeism among student groups could shed significant light on student motivation levels in regular classroom setting. Paying attention to the rationales for class absence provided by students may be helpful in diagnosing the levels of student engagement and respond to the problem in proper ways. It has also been found from literature that absenteeism effect student's ability to learn, achieve, and perform in the examination. The findings of this study is expected to aware the students who are habitual absentee or late comers to assure them the reasons of student absenteeism and how the absenteeism may affect their performance and future carrier, so that they become agree to improve their attendance and reduce absent rate enabling them to attend the lectures regularly.
STATEMENT OF THE PROBLEM -

The problem of the stated as below -

\section{"CAUSES OF STUDENT ABSENTEEISM AT UNDERGRAD UATE LEVEL: A STUDY" \\ OBJECTIVE OF THE STUDY -}

The objective of the study is to study the reasons of student absenteeism from student's perspective.

\section{METHOD OF THE STUDY}

The study is qualitative in nature and descriptive survey method is applied. The sample of the study consists of 60 undergraduate students from three colleges of the area selected purposively who are in the habit of absenting oneself from regular classes. To know the main reasons that impact in the decision of not attending the class, a self-prepared questionnaire consists of 50 statements based on physical, motivational, emotional, teacher and management components has been used for collecting data from the selected students. Data collected were primary in nature and analysed using simple percentage. However, the findings of the study are limited to the selected sample only.

\section{ANALYSIS AND INTERPRETATION -}

The reasons of student absenteeism is presented in the table no 1

Reasons of student absenteeism $\quad \mathrm{N}=60 \quad$ (in \%)

\begin{tabular}{|l|l|l|l|}
\hline $\begin{array}{l}\text { Sl. } \\
\text { No }\end{array}$ & I do not attend the class as I have - & No. & $\%$ \\
\hline 1. & Lack of patience for sitting in the class & 12 & 20 \\
\hline 2. & $\begin{array}{l}\text { The idea that the teachers do not come to } \\
\text { class in the first period }\end{array}$ & 09 & 15 \\
\hline 3. & Difficulty in waking up in the morning. & 17 & 28 \\
\hline 4. & Due to problems in my family, (economic). & 27 & 45 \\
\hline 5. & $\begin{array}{l}\text { Lack of time adjust because of private } \\
\text { tuition. }\end{array}$ & 13 & 21 \\
\hline 6. & $\begin{array}{l}\text { Not motivated/Interested enough to attend } \\
\text { the class. }\end{array}$ & 21 & 35 \\
\hline 7. & The lectures are delivered by strict teachers & 16 & 26 \\
\hline 8. & Believe that can pass without going to class & 11 & 18 \\
\hline 9. & Engaged in part-time work & 18 & 30 \\
\hline 10. & Have the freedom not to attend the class & 21 & 35 \\
\hline 11. & $\begin{array}{l}\text { Thinking about leaving the degree and } \\
\text { begin to work }\end{array}$ & 11 & 18 \\
\hline 12. & Proximity of exams in semester system & 12 & 20 \\
\hline 13. & $\begin{array}{l}\text { Mental capacity does not match with the } \\
\text { subject opted }\end{array}$ & 14 & 23 \\
\hline 14. & Lack of job opportunity for educated & 21 & 35 \\
\hline
\end{tabular}

Submitted : $13^{\text {th }}$ July, 2019

Accepted : $18^{\text {th }}$ September, 2019

Publication : $15^{\text {th }}$ December, 2019 


\begin{tabular}{|c|c|c|c|}
\hline 15. & The content of the subject is very easy & 08 & 13 \\
\hline 16. & $\begin{array}{l}\text { Lack of habit of punctuality to attend the } \\
\text { class }\end{array}$ & 22 & 36 \\
\hline 17. & $\begin{array}{l}\text { Prefer to study by notes instead of attending } \\
\text { classes }\end{array}$ & 18 & 30 \\
\hline 18. & Usually miss the first and last classes & 37 & 61 \\
\hline 19. & $\begin{array}{l}\text { No direct relation between the contents of the } \\
\text { degree and my expectation }\end{array}$ & 16 & 26 \\
\hline 20. & Bad relation with the group & 17 & 28 \\
\hline 21. & Serious personal troubles & 21 & 35 \\
\hline 22. & Health problems & 16 & 26 \\
\hline 23. & Allied activities of college & 09 & 15 \\
\hline 24. & Have anxiety and stress & 11 & 18 \\
\hline 25. & $\begin{array}{l}\text { Obliged to do other activities, banks, } \\
\text { bringing gas cylinder, social function etc }\end{array}$ & 17 & 28 \\
\hline 26 & Worried to be asked in class & 19 & 31 \\
\hline 27 & Will be unable to pass the subject & 12 & 20 \\
\hline 28 & The teacher do not explains with clarity & 11 & 18 \\
\hline 29 & The teacher do not apply interesting method & 18 & 30 \\
\hline 30 & The teacher do not mind in absence & 13 & 21 \\
\hline 31 & $\begin{array}{l}\text { The teacher do not encourages the } \\
\text { participation in the class }\end{array}$ & 11 & 18 \\
\hline 32 & The classes are monotonous and boring & 25 & 41 \\
\hline 33 & $\begin{array}{l}\text { Prefer to study at home, especially when } \\
\text { exams are coming }\end{array}$ & 11 & 18 \\
\hline 34 & $\begin{array}{l}\text { Going to class do not makes easier to } \\
\text { understand the subject }\end{array}$ & 13 & 21 \\
\hline 35 & $\begin{array}{l}\text { The explanations are not adapted to my } \\
\text { understanding }\end{array}$ & 34 & 56 \\
\hline 36 & $\begin{array}{l}\text { In class it is not transmitted the relation } \\
\text { between the subject and its applications }\end{array}$ & 14 & 23 \\
\hline 37 & Have troubles with the transportation & 21 & 35 \\
\hline 38 & The teacher do not motivate the students & 13 & 21 \\
\hline 39 & $\begin{array}{l}\text { With bad weather I don't feel like to go to } \\
\text { class }\end{array}$ & 13 & 21 \\
\hline 40 & The teacher is not interested in the students & 11 & 18 \\
\hline 41 & $\begin{array}{l}\text { The teacher has lack of authority and } \\
\text { discipline in the class }\end{array}$ & 16 & 26 \\
\hline 42 & In the class one's failures are emphasized & 08 & 13 \\
\hline 43 & Students efforts are not valued in the class & 11 & 18 \\
\hline 44 & Have alternative leisure plans & 18 & 30 \\
\hline 45 & $\begin{array}{l}\text { Convinced by my friends for not attending } \\
\text { classes }\end{array}$ & 11 & 18 \\
\hline 46 & Have too many free hours between subjects & 32 & 53 \\
\hline 47 & The missed class system is not rigorous & 19 & 31 \\
\hline 48 & $\begin{array}{l}\text { The materials/strategies used in the } \\
\text { classroom are not adequate }\end{array}$ & 15 & 25 \\
\hline 49 & Studying other subjects & 06 & 10 \\
\hline 50 & Poor infrastructure facility & 17 & 28 \\
\hline
\end{tabular}

\section{MAJOR FINDINGS OF THE STUDY -}

From the frequency analysis, it has been observed that the students mostly express 'I do not attend the classes because I have difficulty in waking up in the mornings, this may be due to more inclination towards social media' and 'I do not attend the classes in order to resolve my family problems as the reasons of their absenteeism that may be due to economic condition or health related issues of the family members. 12 ( $20 \%$ ) students opined that due to proximity of end semester examination they prefer to study at home. Lack of subject interest, lack of personal interest in studies, lack of mental capability and confidence, poor teaching skill allied activities of colleges keeps the students away from classroom. Besides, as the missed class system is not rigorous, interpret it as having freedom of abstaining from classes.
From above discussion it can be observes that the reasons of class absenteeism varied from personal, familial, peer group, teacher concerned, organizational to societal aspects.

\section{SUGGESTION -}

Based on the findings obtained from the study, the following suggestions are made for maintaining balance in student's attendance rate. -

- Proper mechanism for student's attendance should be maintained though it is bit difficult in view of present student teacher ratio.

- The teachers should maintain lessons seriously during the first and last weeks in order to get rid of the idea that no lessons are executed during such times.

- The students should be motivated by using different learning methods and techniques.

- Student's class participation should be encouraged by building a mutually respectful relationship with students and teachers.

- Adjustment on class timing should be made as far possible.

- Collecting fine from absent students may make the students punctual.

- Career counselling, professional motivational sessions should be organized in the academic institutions.

- Academic institutions should also adopt innovative teaching strategies to make the learning process interesting.

- Developing interpersonal relation between the students and teachers should be emphasized.

- Teachers should identify barriers to attendance and address them through interventions, such as collab orating with community organizations to address needs of families and students.

- Administrators should work closely with classroom teachers to identify students with a pattern of absence and collaborate with teachers in sorting the problems.

- Teachers should try to create a rich, engaging, and enjoyable classroom environment for students giving more practical example from real life situation, introducing sudden class test, giving examination tips, bonus marks for full attendance so that students remain excited about attending classes.

\section{CONCLUSION}

Absenteeism is a problem of complex nature that can be solved with the cooperation of students, teacher, management, parents. In this regard, best practices to check this trend is the need of the time by the students, teachers, institutions, parents and policy makers. It impacts not only their academic progress, but social development also. Significant innovations that can be brought by the teachers in their classrooms can be constructive pedagogy through activity based, cooperative, projects and problem - solving methods. Besides, community participation needs to become active in improving the higher education scenario. Regular attendance encourages the students to organize their thinking by comparing new ideas. It plays an important role in enhancing student performance because it helps the student to submit assignment on time, enhance collaboration among student, student achieve greater understanding and improve coordination with teachers and peers.

\section{REFERENCES -}

1. A. Aslihan, and Kuguoglu. H. I.(2010)' Evaluating the reasons for Absenteeism in terms of Different Variables according to their own Perceptions of PreService Teachers" Procedia, Social and Behavioural Science 2 2577-2582

2. Dhalawal Y.(2003) "Absenteeism and underachievement in final year medical students" The National Medical Journal of India, 16 (1) 34-37

3. Khalid N. (2017) "Effects of Absenteeism on Student Performance International Journal of Scientific and Research Publication . Vol 7 Isseau 9 Sept 2017 